\title{
PSITTACOSIS
}

\section{WHAT IS PSITTACOSIS?}

- Psittacosis is an uncommon disease that is usually transmitted to humans from birds. It is caused by a bacteria called Chlamydia psittaci.

\section{HOW IS IT SPREAD?}

- Infection usually occurs when a person inhales the bacteria, usually from dried bird droppings from infected birds. People can also become infected by mouth-to-beak contact (kissing) with birds or by handling the feathers or tissues of infected birds. Psittacosis has not been proven to be spread from person to person.

- All birds are susceptible to infection, but pet birds (for example: parrots, parakeets, cockatiels); and poultry (turkeys and ducks) are most frequently involved in passing the infection to humans.

- People most at risk of infection with psittacosis are those who come into contact with birds through their work or hobbies. For example: bird owners, pet shop employees, vets, or people who process poultry.

\section{WHAT ARETHE SYMPTOMS OF PSITTACOSIS?}

- The time from between human exposure to the bacteria and the development of symptoms varies from about four to 15 days.

- People with psittacosis often develop a flu-like illness, with a sudden onset of fever, chills, headache, weakness and muscle aches. They may also have a dry cough, chest pain and feel breathless. In severe cases, pneumonia develops.

\section{HOW IS PSITTACOSIS DIAGNOSED AND TREATED?}

- If a doctor thinks someone has psittacosis, blood tests can be done to help confirm the diagnosis. Chest Xrays often show pneumonia.
- Psittacosis is treated with antibiotics. These need to be continued for two weeks.

- It is important to try to determine where the infection came from. Other people who may have been exposed to an infected bird should be made aware of the symptoms of infection. The bird should be treated and its environment cleaned with disinfectant to prevent further infections being spread to other people or to other birds.

\section{HOW DO I KNOW IF A BIRD IS INFECTED?}

- In birds, symptoms of the infection can vary from nothing at all to a fatal illness. Sick birds may have symptoms such as diarrhoea, weakness, ruffled feathers, not eating and runny eyes or nose. If in doubt, a vet should examine your bird. Infected birds need to be isolated, treated with antibiotics and have their cages disinfected.

- As it can be difficult to tell if a bird is infected, ensure strict hygiene, including hand washing, when handling pet birds. Avoid kissing (mouth-to-beak contact with) pet birds.

- Birds should be housed in clean cages of ample size that are lined with newspaper that is changed frequently. Faecal material must not accumulate, dry up and allow infected faecal dust to become airborne. Dampen any bird droppings or cages prior to cleaning.

- Birds should only be obtained from a licensed pet store or aviary.

For more information please contact your local public health unit, community health centre, or doctor. 